DOI: $10.33067 /$ SE.4.2020.1

\author{
Krzysztof Feliks Śliwiński ${ }^{\star}$
}

\title{
A Critical Analysis of Europeanism as an Ideology. Its Preconditions and Tenets
}

\begin{abstract}
This paper looks at European integration and specifically at its institutional form - the European Union from an ideological perspective. The author claims that 'Europeanism' has become a new ideology shared among intellectual, political, judicatory, societal, and even dominant economic elites that influence or shape the European Union as an institution and its major policies. As an ideology, 'Europeanism' is a somewhat exotic mixture of various, seemingly incoherent trends that give the current European Union its intriguing characteristics. On the one hand, economically, one can easily identify numerous elements of neoliberalism, especially regarding the financial aspects of European integration. Likewise, arguments used by the major proponents of European integration vis-à-vis USA, China, or Japan are of neoliberal character. At the same time, regarding international trade in agricultural products, intellectual property, or internal (single market) competition (freedom of labour) one rather quickly spots distinct elements of protectionism and over-regulation. Finally, in terms of philosophical outlook and especially moral issues, 'Europeanism' seems to be mostly focusing on the progressive agenda. ${ }^{1}$
\end{abstract}

Keywords: European Union, Ideology, Europeanism

\section{Introduction}

On December 7, 2017, Martin Schulz, leader of the German Social Democrats and former President of the European Parliament, delivered

^ Krzysztof Feliks Śliwiński - Hong Kong Baptist University, e-mail: chris@ hkbu.edu.hk, ORCID: 0000-0001-7316-3714.

1 Brexit - to Deal or not to Deal. Symposium Brexit and the Future of European Integration, http:/gis.hkbu.edu.hk/files/PublicJuristSpecialIssueBrexitSymposium.pdf (access 31.08.2020). 
a speech at the SPD federal party congress calling for the United States of Europe by 2025. "I want there to be a constitutional treaty to create a federal Europe. [...] Once drafted, it would be presented to the member states, and those who are against it will simply leave the EU". ${ }^{2}$

Guy Verhofstadt, the former leader of the Alliance of Liberals and Democrats for Europe in the European Parliament, (also the 47th Prime Minister of Belgium and the European Parliament's Brexit Coordinator and Chair of the Brexit Steering Group) a passionate federalist, famously declared during one of the EP sessions that "You will have to repeat it there, telling them that the intergovernmental method is a bad method that cannot work. [...] We have to abolish it. [...] We all know that the only way out of this crisis is a new transfer of powers to the European Union and to the European institutions". ${ }^{3}$

Finally, Donald Tusk former President of the European Council (also former Prime Minister of Poland and the leader of the Civic Platform party) commenting on the then-ongoing Brexit negotiations stirred much criticism, especially in Britain, for uttering this brief sentence: "I've been wondering what that special place in hell looks like for those who promoted Brexit without even a sketch of a plan how to carry it out safely". ${ }^{4}$ A comment, which was seen by many as a proof of Brussels's impertinence, far removed from expected and often self-proclaimed professionalism.

These three examples are naturally anecdotal and do not prove much. At most, they can testify to the fact that political leaders are human beings, and like all of us, they do succumb to emotional states. They are, however, quite typical for many among the unabashed supporters of the European Union.

This paper starts with a query regarding the nature of the European Union. It posits that the institutional form of European integration has achieved by now a peculiar level - tantamount to ideology. In short, it is claimed that the proponents of the European Union (intellectual, political, judicatory, societal, and dominant economic elites) tend to increasingly see the world and the EU in terms of a Manichean black-and-white perspective, whereby there appears no space for nuances and per consequence any critical thinking regarding the European Union.

2 J. Delcker, SPD's Martin Schulz wants United States of Europe by 2025, "Politico", 12 July 2017.

3 G. Verhofstadt, Debates, European Parliament, 28 September 2011, http:// www.europarl.europa.eu/sides/getDoc.do?pubRef=-//EP//TEXT + CRE + 20110928 + ITEM-003 +DOC + XML + V0//EN\&language $=$ EN (access 29.08.2010).

4 BBC News, Donald Tusk: Special place in hell for Brexiteers without a plan, BBC, 6. February 2019, https://www.bbc.com/news/uk-politics-47143135 (access 29.08.2010). 
This paper does not postulate particular actions, much less validate any philosophical outlooks. Neither does it analyse the ideological underlining of the contemporary European Union and its various institutions. Instead, by analysing numerous documents, speeches and actions of multiple actors, it concludes that the European Union and European integration have achieved a status equivalent to ideology in its own right. An ideology that for lack of a better term is referred thereof as 'Europeanism'. This, in turn, offers much needed explanatory power for all those trying to understand contemporary EU and European politics.

In terms of epistemology, the notion of ideology is employed in this paper very much against the postulates made by the post-modernists or the post-structuralists, in particular, who not only question the classical meaning of ideology but even its existence. ${ }^{5}$ On the contrary, the author departs from the assumption that Fukuyama's thesis is to be defended only in so far as he referred to the battle between the capitalist vs communist ideologies. The ideological battles are still present at the beginning of the twenty-first century which was rightly pointed by Fred Zakaria. That is to say, ideology in one form or another seems to be indispensable for homo politicus, and perhaps the greatest danger of all is to assume that there are no ideologies left. ${ }^{6}$

Most students of political science are introduced to basic notions such as ideology by Andrew Heywood. Accordingly, they are told that "an ideology is a more or less coherent set of ideas that provides the basis for organised political action, whether this is intended to preserve, modify or overthrow the existing system of power. All ideologies, therefore, have among others, the following features:

a) They offer an account of the existing order, usually in the form of a 'world-view.'

b) They advance a model of the desired future, a vision of the 'good society.'

c) They explain how political change can and should be brought about - how to get from (a) to (b)". ${ }^{7}$

There is, however, several characteristics of ideology that need to be borne in mind before we proceed with our analysis. As Brian Turner reminds us, ideology is to be seen as a complex process "by which meaning is produced, challenged, reproduced, transformed", "An ideology always embodies particular arrangements of power and affects life chances in

5 T. Eagleton, Ideology An Introduction, Verso, London, New York 2007, p. XX.

6 S. Žižek, The Sublime Object of Ideology, Verso, London, New York 2008.

7 A. Heywood, Political Ideologies. An Introduction, $3^{\text {rd }}$ ed, Palgrave Macmillan, London 2017. 
a manner that is different from some other ideology or arrangement of power". ${ }^{8}$ That is to say, ideologies are peculiar to a certain way of thinking. They stem from particular societal, cultural, political or geographical circumstances. As such, their pretences to objectivity have to be dismissed by default.

Secondly, and consequently, as Raymond Boudon points out drawing on Raymond Aron, ideologies rely heavily not on facts but indeed on value judgements. As much as facts are demonstrable and therefore can be validated, value judgments cannot. ${ }^{9}$ Value judgements cannot be proved true or false. They are susceptible to being correct. At the same time, Boudon asserts that ideologies are distinct from other belief systems in the way they meet eight specific criteria: the explicit nature of their formulation, their wish to rally people to particular positive or normative belief (underlined by author), their desire to be different from other belief systems past or present, their rejection of innovation, the intolerant nature of their precepts, the affective way they are promulgated, the adherence they demand, and finally their association with institutions responsible for reinforcing and putting into effect the Belief systems in question. ${ }^{10}$

Again, none of these allows us to think about ideologies as systematic, objective and scientific approaches to the comprehension of social phenomena and consequent prescriptions for policymakers.

Thirdly, as van Dijk instructs us, an essential feature of all ideologies is that they tend not to be consistent. "Indeed, ideologies are cognitively and socially constructed, naive basic 'theories' of social life, and especially about groups and their relations to other groups". ${ }^{11}$ This is an important observation as more often than not ideologies prove to be practical yet, hardly coherent and logical systems of belief which though serve as powerful tools in the hands of certain groups (groups of power) importantly lack the logical rigidity much less flexibility required by real-life situations.

Lastly, and correspondingly, as Eagleton asserts, another feature of ideology turns our attention to ideas and beliefs (whether true or false) which symbolise the conditions and life experiences of a specific, socially significant (underlined by author) group or class. ${ }^{12}$ In other words, the ideology is close to the idea of a 'world view' and as such is characteristic

8 S.B. Turner, Cambridge Dictionary of Sociology, Cambridge University Press, Cambridge 2006.

9 R. Boudon, The Analysis of Ideology, Polity Press, Oxford 1989, p. 19.

10 Ibidem, p. 20.

11 T.A. van Dijk, Ideology. A multidisciplinary approach, Sage, London 1998, p. 91.

12 T. Eagleton, Ideology. An Introduction, Verso, London 2007. 
to a particular group of people. The group of people, which is powerful or influential enough to advertise it and apply in practice.

For reasons of academic honesty and diligence, we note that the term 'Europeanism' has been applied before. Most often cited in this regard is much revered John McCormick and his seminal publication titled, nomen omen 'Europeanism'. Published precisely ten years ago, his book remains one of those introductory readings for students and practitioners of European integration. Drawing on Habermas and Derrida, McCormick identifies not fewer than ten (sic!) attributes of 'Europeanism'. They are the European identity that supplants nationally based citizenship and patriotism, cosmopolitanism, communitarianism, collective society, welfarism, sustainable development, redefinition of the family, post-materialism, opposition to capital punishment (greater emphasis on individual rights, and a preference for resolving disputes through negotiation rather than confrontation through the law), multiculturalism, secularism, perpetual peace and last but not least multilateralism. ${ }^{13}$

Each of these traits is valued positively, and one might even say 'taken for granted' without much deliberation by the majority of EU citizens, policymakers or intellectual elites. However, by the end of the second decade of the twentieth century, it seems essential to revisit the subject of ideology in and of the European politics and therefore validate these claims, which is precisely what this paper intends to do. ${ }^{14}$ Indeed, the last ten years have brought developments that challenge every one of the presented attributes, rendering them more postulates rather than actual characteristics of existing social phenomena.

\section{'Europeanism' - From an Idea to an Ideology}

European integration as a project is comparatively juvenile. Commenced in 1950 (by the Schuman Declaration) it was initially based as we know on pragmatic, mostly economic agenda albeit with crucial political foundations and consequently - political ramifications. After 69 years it has grown substantially to involve several political, institutional and ideological elements.

Adding to the examples cited at the beginning of this paper, French President Emmanuel Macron published his vision for the European integration titled: For European renewal. Addressing all European citizens

13 J. McCormick, Europeanism, Oxford University Press, Oxford 2010.

14 Due to limited space it is not possible to address and validate each and every attribute as proposed by McCormick. Instead a much narrower set of attributes is proposed. 
(sic!), Macron paints a bold picture of the future that very much resonates with Martin Schultz's earlier remarks. As in a nutshell, it shows how the idea of cooperation instead of competition has evolved into an institutionalised form which, through 'splill over' or not, emerged as an overriding and unchallenged assumption that there is no way back and that more integration is always better than less - "We have to stand firm, proud and lucid, in the face of this manipulation and say first of all what Europe is. It is a historic success: the reconciliation of a devastated continent in an unprecedented project of peace, prosperity and freedom. We should never forget that. And this project continues to protect us today. What country can act on its own in the face of aggressive strategies by the major powers? Who can claim to be sovereign, on their own, in the face of the digital giants? How would we resist the crises of financial capitalism without the Euro, which is a force for the entire European Union? [...] The nationalists are misguided when they claim to defend our identity by withdrawing from Europe because it is the European civilisation that unites, frees and protects us". ${ }^{15}$

These lines offer themselves as a useful example of the hypothesis put forward at the beginning of this paper, namely that the European integration has come to function as ideology, which does not have to seek any justification and supposedly explains it all. Interestingly, Joseph Schumpeter foresaw such a phenomenon in the context of bureaucratisation which according to him had to, sooner or later, limit the democratic system in the name of its effectiveness ultimately leading to the destruction of the capitalism altogether. ${ }^{16}$

This corresponds with the first and second characteristics of ideology mentioned earlier. Ideologies are peculiar to a certain way of thinking. They stem from particular societal, cultural, political or geographical circumstances. They embody a peculiar set of world views, which tend to be based on specific, established combination of elements: firstly, since ideologies are meant to give answers to fundamental problems that a particular society faces, once established they do not lend themselves to criticism easily. Secondly, and consequently, they de facto eliminate any alternatives by virtue of their dominant position. Thirdly and quite logically, they are highly normative as fourthly, they are introduced/imposed by the dominant social power. ${ }^{17}$ One might perhaps add drawing on Eagleton that

15 Élysée, For European renewal, March 4 2019, https://www.elysee.fr/emmanuelmacron/2019/03/04/for-european-renewal.en (access 29.08.2010).

16 W. Davies, The Limits of Neoliberalism. Authority, Sovereignty and the Logic of Competition, SAGE, Los Angeles 2017, p. 55.

17 T. Eagleton, op. cit., p. 29. 
every ideology needs its champions - particularly passionate individuals who command social attention and enjoy high prestige.

\section{Ideological Preconditions of 'Europeanism'}

'Europeanism' asserts its position claiming universality (at least in the European context). European values, which seem to make the crucial element of its contents are taken for granted and recently used as an instrument in political battles between national governments, various political parties representing the right and the left, non-state political actors such as NGOs or even EU institutions themselves.

In May 2018 the European Commission proposed a new mechanism to protect the EU budget from financial risks linked to "generalised deficiencies regarding the rule of law" in member states. This would allow the Union to suspend, reduce or restrict access to EU funding in a manner proportionate to the nature, gravity and scope of the rule of law deficiencies. Such a decision would be proposed by the Commission and adopted by the Council through reverse qualified majority voting, making it all but impossible for one or two countries to block punitive measures. As the Commission elaborately puts it in the document: "[...] In order to protect the Union's financial interests from the risk of financial loss caused by generalised deficiencies as regards the rule of law in a Member State, the European Union should be granted the possibility to adopt appropriate measures in such cases". ${ }^{18}$

Special meeting of the European Council 17-21 July 2020 which decided the next Multiannual Financial Framework - MFF (in the context of COVID-19 pandemics), in principle linked the rule of law principle with the future budgets of the EU (point 23 of the Council Conclusions). ${ }^{19}$ At the same time the majority of parties in the European Parliament, including the centre-right European People's Party, the Socialists \& Democrats, the liberal Renew, the Greens and the far-left GUE agreed on a resolution which openly questioned the EU summit and its laborious compromise: "(the EP) Strongly regrets the fact that the European Council significantly weakened the efforts of the Commission and Parliament to uphold the rule of law, fundamental rights and democracy in

18 Regulation of the European Parliament and of The Council on the protection of the Union's budget in case of generalised deficiencies as regards the rule of law in the Member States, 2018.

19 See more at: Special meeting of the European Council (17, 18, 19, 20 and 21 July 2020) - Conclusions, Brussles 21 July 2020, https:/data.consilium.europa.eu/ doc/document/ST-10-2020-INIT/en/pdf (access 20.10.2020). 
the framework of the MFF and the Next Generation EU (NGEU) instrument; reconfirms its demand to complete the co-legislator's work on the Commission's proposed mechanism to protect the EU budget where there is a systemic threat to the values enshrined in Article 2 of the TEU, and where the financial interests of the Union are at stake; stresses that, to be effective, this mechanism should be activated by a reverse qualified majority; underlines that this mechanism must not affect the obligation of government entities or of Member States to make payments to final beneficiaries or recipients; underlines that the Rule of Law Regulation will be adopted by co-decision". ${ }^{20}$

Furthermore, 'Europeanism' achieves its universal status by equalising the European Union with Europe. Therefore everything that the European Union does as an institution or is proclaimed/conveyed in its name becomes European as if it represents the whole of Europe. This has essential linguistic and psychological ramifications. Firstly, it excludes those countries that are geographically located in Europe but do not belong to the EU, casting doubts over their Europeanness - Island, Switzerland, Norway, UK, Serbia or Belarus to name just a few. Secondly, it creates an elitist platform providing its members and functionaries with an illusionary conviction that the European Union as a form of international cooperation offers the not only economically most efficient but morally highest level of organisation to be emulated by the rest of the world. ${ }^{21}$

Logically then, there can be no viable alternative to European integration and the EU. As Euro enthusiasts often put it: if there is no EU, there is nationalism, disintegration and war in the end. After all, as one of the greatest Euro-enthusiasts, Guy Verhofstadt, known for emotional speeches in the European Parliament himself adamantly put it in his book (Europe's Last Chance: Why the European States Must Form a More Perfect Union): "«United States of Europe» will be better able to stop the next terrorist attack, to respond to the next economic downturn, to listen to the voices of the people before it's too late. Fragmented as it is, Europe

20 See more at: European Parliament resolution on the conclusions of the extraordinary European Council meeting of 17-21 July 2020, https://www.europarl.europa. eu/doceo/document/B-9-2020-0229_EN.html (access 20.10.2020).

21 As one of many examples of the tendency for the EU pundits to mix European with the EU, please consult: White paper on the future of Europe: Drivers of Europe's Future, https://ec.europa.eu/commission/future-europe/white-paper-future-europe/white-paper-future-europe-drivers-europes-future_en. Another telling example is the annually worldwide held celebrations of 'Euorpe Day'/Journée de l'Europe'/'Europatag' which in fact commemorates the beginning of the European integration, https://eeas.europa.eu/headquarters/headquarters-homepage/77987/europe-day-2020-together-we-are-europe_en (access 20.10.2020). 
today can barely tread water as it fails to respond to the refugee crisis, the sputtering economy, and the rise of terrorism and xenophobic politics. Devastating internal divisions that limit our ability to respond effectively undermine even the seeming unity of scorned Europeans after the Brexit vote. Many say that the European Union is at the breaking point, and they are right. Yet the solution is not less Union but more. Europe desperately requires a new, federal government modeled on the United States...". ${ }^{22}$

Lastly, as mentioned before, since it is implied that Europe is the European Union and vice versa, it reasonably follows that to be European automatically means to be an unabashed enthusiast of European Union. Conversely, if one raises critical questions regarding the nature of European politics within the framework of European integration and specifically European Union, anti-European attitude is self-evident. For instance, quite recently Jan-Werner Müller, a professor of politics at Princeton University, published a representative op-ed at Foreign Policy online, under the self-explanatory title: "If You're Not a Democracy, You're Not European Anymore". ${ }^{23}$ The author claims that by activating the so-called "nuclear option" by the European Commission against Poland on December 20 2017, invoking the article 7 of the Lisbon Treaty: "The commission, the official "guardian of the European treaties,» charged that the Polish government's so-called reforms of the judiciary posed a serious threat to basic European values, in particular the rule of law" (underlined by author). He goes on to assert that the action taken by the European Commission should not be seen as yet another proof of European crisis (or one of many crises to be precise) but "If anything, the Commission did the right thing for European integration by taking a stand on what exactly the EU stands for and what membership in it means. The alternative would have been turning a blind eye to a slow erosion of democracy and the rule of law in several member states - a process that calls the very core of European integration as a political project into question". ${ }^{24}$

This short extract serves well as an illustration of a particular trait, which is shared by most 'Euro-enthusiasts'. The proponents of European integration and by extension of the European Union tend to depart from a unique set of assumptions. Firstly, they seem to claim that there is no viable alternative to the European Integration and its institutional form.

22 G. Verhofstadt, Europe's Last Chance. Why the European States Must Form a More Perfect Union, Basic Books, New York 2017, p. 406.

23 J.W. Müller, If You're Not a Democracy, You're Not European Anymore, "Foreign Policy", 22 December 2017, https:/foreignpolicy.com/2017/12/22/if-youre-not-a-democracy-youre-not-european-anymore/ (access 29.08.2010).

${ }^{24}$ Ibidem. 
In this context, the sole idea of Brexit is seen as irrational. To question the European integration and EU, itself is equivalent to going against pure reason. Secondly, it implied that almost any criticism of Europe and European integration or the EU, especially the one that departs from national positions, is a proof of 'right-wing populism', 'sovereigntizm' and will inevitably lead to fascism. At the least, it is an effect of deliberate misinformation and low level of education not mentioning the emotional attitude to politics and traditional (outdated) philosophical outlook accompanied by equally obsolete moral code.

Last but not least as 'Europeanists' enthusiastically put forward the European Integration is a process and it can only go forward, once it stops the EU is bound to fall apart, which will inevitably induce disintegration and "cast as back to the dark ages". ${ }^{25}$

\section{Exploring 'Europeanism' and Its Tenets}

Finally, let us have a look at major tenets that feature prominently in 'Europeanism'. As an ideology 'Europeanism' is a somewhat exotic mixture of various seemingly incoherent trends that give current European Union its intriguing characteristics.

On the one hand, economically, one can quickly identify numerous elements of neoliberalism, especially regarding the financial aspects of European integration. Likewise, arguments used by the major proponents of the European integration vis-à-vis USA, China or Japan are of neoliberal character.

On October 30 2016, the day of the EU-Canada Comprehensive Economic and Trade Agreement (CETA) signing, Guy Verhofstadt declared on his Facebook account: "I am happy that European and Canadian leaders formally signed their EU-Canada free trade pact today. In times of increasing globalisation, a retreat to protectionism will make us poorer. We should use agreements like \#CETA to set the framework and rules for global connectivity ourselves". ${ }^{26}$ The then President of the European Parliament Martin Schulz and the President of the European Commission have been also openly enthusiastic, indicating the new "benchmark" in EU-Canada relations as well as the "golden standard" in international trade agreements. ${ }^{27}$ The then President of the European Council Donald

25 T.G. Ash, Brexit is just one front in Europe's battle for its soul, "The Guardian", 9 April 2019, https://www.theguardian.com/commentisfree/2019/apr/09/brexit-europe (access 29.08.2010).

26 See: https://www.facebook.com/GuyVerhofstadt/ (access 29.08.2010).

27 See: https://twitter.com/JunckerEU (access 29.08.2010). 
Tusk went even further, declaring on his Twitter account: "Free trade and globalisation have protected humanity from poverty, hunger and total conflict. Few people seems to believe this today". ${ }^{28}$

Notably, the list of counterarguments against CETA at a time of negotiations was rather lengthy. The many opponents of the CETA between the EU and Canada prominently feature The Greens-European Free Alliance in the European Parliament (Greens/EFA), who resolutely oppose CETA for twelve reasons. These reasons are not only fundamentally crucial from the procedural standpoint, but they principally refer to the content of the agreement. According to The Greens, unlike in the case of TTIP, during the CETA negotiations the European Commission never released the documents before the final text of the agreement was published (The Greens/European Free Alliance, 2017). The European Parliament members and parliamentarians across Europe alike could not, therefore, have access to the text. At the same time, it was being negotiated, thereby depriving European societies of their fundamental right to scrutinise the policy-making process. ${ }^{29} \mathrm{Fur}$ thermore, the Green/EFA claims that particularly worrying, are those stipulations which provide for investor-state dispute settlement (ISDS), which allows foreign investors to sue nations if they feel that new laws or regulations have impacted their businesses. ${ }^{30}$ Other concerns include: locking-in current and further liberalisation, thereby making it very difficult (and costly) for countries to bring services back into public ownership; increased costs to public healthcare systems due to changes in patent protection for pharmaceutical drugs; further contribution to the pro-GMO (genetically modified organisms) pressure on the EU regulatory processes; weakening the Fuel Quality Directive (FQD), which is allegedly a crucial piece of law aimed at reducing the EU's carbon emissions; weakening the rules which aim to benefit local communities and municipalities in terms of employment and sustainability; procuring the facilitation of only the "most beneficial" or "the cheapest offer" mechanisms when tendering; providing no binding rules to protect and improve workers rights and environmental protection; introducing further

28 See: https://twitter.com/eucopresident (access 29.08.2010).

29 See: R. Aline, "Strange" manoeuvering over CETA exposes democratic deficit, Euractiv, 13th October, 2016, http://www.euractiv.com/section/trade-society/news/strangemaneuvering-over-ceta-exposes-democratic-deficit/ (access 20.10.2020).

30 This is a particularly controversial mechanism. For more information and analysis please see: M. Geist, The devil's in CETA's details, specifically on dispute settlement, The Globe and Mail, 25th October, 2016, https://www.theglobeandmail.com/ report-on-business/rob-commentary/the-devils-in-cetas-details-specifically-on-dispute-settlement/article32492826/ (access 20.10.2020). 
completion mechanism which will probably affect farmers; containing pro-industry provisions which curb the regulatory space for governments to act with regard to the Paris Agreement provision limiting $\mathrm{CO}_{2}$ emissions; and, finally, expanding foreign investor-rights tenfold, which may result in $81 \%$ of US subsidiaries in the EU being able to launch ISDS attacks with CETA alone. ${ }^{31}$

At the same time, regarding international trade in agricultural products, intellectual property or internal (single market) competition (freedom of labour) one relatively quickly spots distinct elements of protectionism and overregulation. Historical examples are referring to the notorious 'banana wars, WTO negotiations regarding the international trade in agricultural products (the infamous Doha Round) or the ultimate failure of the EU to effectively reduce its $\mathrm{CO}_{2}$ emissions within the global framework of COP (Conference of the Parties - United Nations Climate Change) and its European Union Emission Trading Scheme (EU ETS) launched in 2005.

More recently however against the backdrop of economic crisis, In September 2019, the European Parliament's Transport Committee gave the 'green light' to begin negotiations with the European Commission and the Council on rules for reforming the EU's transport sector. The goal is to reach a compromise on the rules known as the "Macron Package", which introduces new regulations for posted drivers, including a higher minimum wage and regulation of their stay in hotels. The most contentious issue appears to be the return of empty trucks to their country of origin once every four weeks. This would prevent transport companies from Central and Eastern Europe from providing their services to the market of Western Europe, the so-called "cabotage". ${ }^{32}$ Bulgaria, Romania, Poland, Hungary, Latvia and Lithuania oppose the proposed regulation claiming that the obligation to return empty trucks would be an illegal protectionist measure that would seriously affect companies in their respective countries, and lead to the loss of jobs and increased economic emigration. It appears that it is the Bulgarian representatives who are among the most vocal opponents of the contested package. Peter Vitanov (Bulgarian Member of the European Parliament) estimated that the Bulgarian government and the local transport industry should make compromises with some of the changes to negotiate the cancellation of the most controversial proposals. "The return of the empty truck [to the country of

31 Other telling examples of neoliberal characteristics of 'Europeanism' might include the functioning of the EURO zone and the position of the European Central Bank (ECB) or German industries, especially electromechanics and energy.

32 https://euractiv.com/topics/mobility-package (access 20.10.2020). 
origin] is contrary to a fundamental principle [author's annotation] of the EU - the free movement of goods and capital". This means that Bulgaria can begin negotiations to seek a compromise with the threat of a dangling court case. "There is no way to oblige anyone to go somewhere else. It is contrary to the free market", according to the Bulgarians.

The posted workers directive (Directive $96 / 71 / \mathrm{Ec}$ ) of the European Parliament and of the Council of December 16 1996, concerning the posting of workers in the framework of the provision of services, is illustrative in this context. Available data published by the European Commission (Employment, Social Affairs \& Inclusion) ${ }^{33}$ indicate that Germany, being a long-term EU member and a strong economy, receives the most significant number of posted workers. If we refer to All 15 long-term members of the EU, we will see that they all receive high numbers of posted workers. On the other hand, all the recently admitted EU member states receive much fewer posted workers, which arguably is likely to be the consequence of much lower levels of economic development there. It is against this backdrop that Bulgaria is expected to seek the cancellation of the part of the so-called Mobility package (also known as the Macron Package) before the Court of Justice of the European Union.

Finally, in terms of philosophical outlook and especially moral issues, 'Europeanism' seems to be mostly focusing on the progressive agenda. Put within a framework of human rights, sexual minorities seem to get unproportionate large attention on the part of liberal-democratic elites both at the level of the EU Member States or the EU institutions.

According to Vocal Europe (a Brussels-based Think Tank, which specialises in research on EU diplomatic actions, enlargement policy and democracy, Europe is currently one of the best if not be the best place in the world for LGBTI individuals. Accordingly, eight out of the ten most LGBT friendly countries in the world are located in Europe, and all are members of the EU. ${ }^{34}$ Still, especially newer members of the EU are frequently criticised by numerous NGO's and the EU institutions themselves for apparently lacking behind in LGBTI friendly regulations.

Back in February 2014, the European Parliament adopted a resolution on EU Roadmap against homophobia and discrimination on the grounds of sexual orientation and gender identity (2013/2183(INI)). The document calls on the Commission, Member States and relevant agen-

33 See: https://ec.europa.eu/social/keyDocuments.jsp?pager.offset $=0$ \&langId $=$ en $\&$ mode $=$ advancedSubmit\&advSearchKey = PostWork (access 20.10.2020).

34 A. Armbrecht, 10 Ways to Improve LGBT Rights in Europe, "Vocal Europe", 1 April 2018, https://www.vocaleurope.eu/10-ways-to-improve-lgbt-rights-in-europe-2/ (access 29.08.2010). 
cies to work jointly on a comprehensive multiannual policy to protect the fundamental rights of LGBTI people, i.e. a roadmap, a strategy or an action plan featuring the themes and objectives including mostly nondiscrimination clauses. (European Parliament resolution of February 4, 2014, on the EU Roadmap against homophobia and discrimination on the grounds of sexual orientation and gender identity (2013/2183(INI)). Consequently, the Commission published a list of priorities shortly afterwards. ${ }^{35}$ Furthermore, in December 2015 it published the List of Actions to Advance LGBTI Equality to move LGBTI equality forward. European Council adopted the first-ever conclusions on LGBTI equality in June 2016 requiring the Commission to annually report on the implementation of the list of actions, which was duly followed by the Commission. ${ }^{36}$

As of 2020, European Commission boasts a whole range of initiatives and activities that promote LGBTI friendly environment. From antidiscrimination legislation in the context of employment, through establishing a Platform of Diversity Charters to encourage businesses, public bodies and non-profit organisations to strengthen their commitment to improving diversity. Importantly, in 2016 the European Commission agreed with Facebook, Twitter, YouTube and Microsoft on a code of conduct which asks them to review the majority of notifications of illegal hate speech within 24 hours and to remove such content if necessary. Instagram, Snapchat, Dailymotion and jeuxvideo.com signed up to the code of conduct in 2018 and 2019. Finally, the Commission supports LGBTI directly or indirectly through funding civil society and in particular those NGOs that promote LGBTI rights such as IGLA-Europe (International Lesbian, Gay, Bisexual, Trans and Intersex Association-Europe). ${ }^{37}$

All this engagement prompts researchers to investigate the role of LGBTI in the context of European/EU politics. So much so that as Slootmaeckers claims, the EU has been effectively building its identity around LGBT promotion. Accordingly, The European Union sees itself as a beacon of lesbian, gay, bisexual and transgender friendliness and seeks to promote these norms in its external relations. ${ }^{38}$ This latter aspect is very relevant

35 See: https://ec.europa.eu/info/policies/justice-and-fundamental-rights/combatting-discrimination/tackling-discrimination_en (access 20.10.2020).

36 See: https://www.consilium.europa.eu/en/press/press-releases/2016/06/16/epsco-conclusions-lgbti-equality/ (access 20.10.2020).

37 See: Spotlight on the EU and the LGBTI Equality, https://op.europa.eu/webpub/ com/factsheets/lgbti/en/ (access 20.10.2020).

38 K. Slootmaeckers, Constructing European Union Identity through LGBT Equality Promotion: Crises and Shifting Othering Processes in the European Union Enlargement, "Political Studies Review", 18(3)/2020, pp. 346-361, DOI: https://doi.org/10.1177/ 1478929919877624. 
in terms of EU public policy outside Europe where admittedly the LGBTI rights promotion is frequently received less enthusiastically due to cultural differences.

\section{Conclusions}

As an ideology 'Europeanism' can be seen therefore as a somewhat incomprehensible amalgamate of seemingly clashing ingredients. What seems to bond these is once again a peculiar conviction on the part of European political elites (both EU Member states and EU institutions), mostly based historically, that Europe/EU represents the highest, most advanced and fairest level of socio-economic cooperation in the international system. This conviction is self reproductive in no small extent. It manifests itself with three distinct, yet logically intertwined (albeit genuinely indigenous and therefore highly subjective) three premises that seem to hold absolute value for the disciples of 'Europeanism'. Firstly, most if not everything that is EU/European related is of positive value. Secondly, and consequently, most if not everything that is EU/European related is positive for all parties involved. If not in the short term, then in the long term. Thirdly, most if not everything that is EU/European related brings an added value to the whole world.

Other related aspects of 'Europeanism' that beg thorough and systematic queries involve European identity, which was briefly mentioned before, the role of 'Europeanism' pundits (increasingly academics themselves, who tend to depend increasingly on European Union funding for the development of their careers), the interpretation of the founding treaties and their subsequent amendments, or finally, the role of the judges of the Court of Justice the European Union ('judgization') in shaping European policies.

One cannot but notice a certain level of cognitive bias among many of the 'Euro enthusiasts' which to a large degree fuel the phenomenon of ' $\mathrm{Eu}$ ropeanism'. When reality does not conform with the theory, they tend to criticise reality. They simply do not accept it as such and consequently create all kinds of reasons to support the theory. In other words, in case of any disparity between reality and theory, for the 'Europeanists' the only imagined way is the way forward, which is to apply more of the same. Previous immigration crisis of 2015 seems to be a rather telling example. Likewise, COVID-19 pandemics has clearly shown that Euro enthusiasts will call for more integration claiming that the apparent weakness of the EU in the face of the COVID-19 disaster is rooted in the lack of political power transferred to the EU and, consequently, still too much power retained by 
the EU Member States. In other words, the current weakness of the EU is called upon to be proof of an urgent need for more Union in the EU.

Correspondingly, Eurosceptics will claim that the current health and economic problems most EU Members face are caused by the apparent 'Brusselization' of European politics, which further fuels Euro-scepticism. Crisis as such time and again proves to be a potent accelerator of ideological differences.

Žižek unmistakably reminds us how the very notion of post-ideology can enable the deepest, blindest form of ideology. A sort of false consciousness or false cynicism, engaged in for the purpose of lending one's point of view the respect of being objective, pretending neutral cynicism, without truly being so. Rather than help avoiding ideology, this lapse only deepens the commitment to an existing one. ${ }^{39}$

\section{References}

Aline R., "Strange" manoeuvering over CETA exposes democratic deficit, Euractiv, 14 October 2016, http://www.euractiv.com/section/trade-society/news/strange-maneuvering-over-ceta-exposes-democratic-deficit/ (access 29.08.2010).

Armbrecht A., 10 Ways to Improve LGBT Rights in Europe, "Vocal Europe", 1 April 2018, https://www.vocaleurope.eu/10-ways-to-improvelgbt-rights-in-europe-2/ (access 29.08.2010).

Ash T.G., Brexit is just one front in Europe's battle for its soul, "The Guardian", 9 April 2019, https://www.theguardian.com/commentisfree/2019/ apr/09/brexit-europe (access 29.08.2010).

BBC News, Donald Tusk: Special place in hell for Brexiteers without a plan, BBC, 6. February 2019, https://www.bbc.com/news/uk-politics-47143135 (access 29.08.2010).

Brexit - to Deal or not to Deal. Symposium Brexit and the Future of European Integration, http://gis.hkbu.edu.hk/files/PublicJuristSpecialIssueBrexitSymposium.pdf (access 31.08.2020).

Boudon R., The Analysis of Ideology, Polity Press, Oxford 1989.

Davies W., The Limits of Neoliberalism. Authority, Sovereignty and the Logic of Competition, SAGE, Los Angeles 2017.

Delcker J., SPD's Martin Schulz wants United States of Europe by 2025, Politico, 12 July 2017. https://www.politico.eu/article/spds-martinschulz-wants-united-states-of-europe-by-2025 (access 20.10.2020).

Dijk van T.A., Ideology. A multidisciplinary approach, Sage, London 1998. Eagleton T., Ideology an Introduction, Verso, London, 2007.

39 S. Žižek, The Sublime Object of Ideology, Verso, London, New York 2008, pp. 25-27. 
Élysée, For European renewal, March 4 2019, https://www.elysee.fr/ emmanuel-macron/2019/03/04/for-european-renewal.en (access 29.08.2010).

European Commission, Proposal for a Regulation Of The European Parliament And Of The Council on the protection of the Union's budget in case of generalised deficiencies as regards the rule of law in the Member States, 2 May 2018, https://eur-lex.europa.eu/legal-content/EN/TXT/P DF/?uri=CELEX:52018PC0324\&from $=\mathrm{EN}$ (access 20.10.2020).

European Parliament resolution of February 42014 on the EU Roadmap against homophobia and discrimination on grounds of sexual orientation and gender identity (2013/2183(INI)), https://www.europarl.europa.eu/sides/getDoc.do?type $=$ TA\&reference $=$ P7-TA-20140062\&language $=\mathrm{EN}($ access 20.10.2020).

European Parliament resolution on the conclusions of the extraordinary European Council meeting of 17-21 July 2020, https://www.europarl.europa.eu/doceo/document/B-9-2020-0229_EN.html (access 20.10.2020).

https://www.facebook.com/GuyVerhofstadt/ (access 29.08.2010).

https://twitter.com/JunckerEU (access 29.08.2010).

https://twitter.com/eucopresident (access 29.08.2010).

Heywood A., Political Ideologies. An Introduction, 3rd ed., Palgrave Macmillan, London 2017.

McCormick J., Europeanism, Oxford University Press, Oxford 2010, DOI: https://doi.org/10.1093/acprof:oso/9780199556212.001.0001.

Müller J.W., If You're Not a Democracy, You're Not European Anymore, "Foreign Policy", 22 December 2017, https://foreignpolicy.com/2017/ 12/22/if-youre-not-a-democracy-youre-not-european-anymore/ (access 29.08.2010).

Regulation of the European Parliament and of the Council on the protection of the Union's budget in case of generalised deficiencies as regards the rule of law in the Member States, 2018.

Slootmaeckers K., Constructing European Union Identity through LGBT Equality Promotion: Crises and Shifting Othering Processes in the European Union Enlargement, "Political Studies Review", no. 18(3)/2020, DOI: https://doi.org/10.1177/1478929919877624.

Special meeting of the European Council (17, 18, 19, 20 and 21 July 2020) - Conclusions, Brussles July 21 2020, https://data.consilium.europa. $\mathrm{eu} / \mathrm{doc} /$ document/ST-10-2020-INIT/en/pdf (access 20.10.2020).

Turner S.B., Cambridge Dictionary of Sociology, Cambridge University Press 2006, https://search.credoreference.com/content/entry/cupsoc/ ideology/0 (access 29.08.2010). 
Verhofstadt G., Debates, European Parliament, 28 September 2011, http:// www.europarl.europa.eu/sides/getDoc.do?pubRef=-//EP//TEXT + $\mathrm{CRE}+20110928+\mathrm{ITEM}-003+\mathrm{DOC}+\mathrm{XML}+\mathrm{V} 0 / / \mathrm{EN} \&$ language $=\mathrm{EN}$ (access 29.08.2020).

Verhofstadt G., Europe's Last Chance. Why the European States Must Form a More Perfect Union, Basic Books, New York 2017.

Žižek S., The Sublime Object of Ideology, Verso, London, New York 2008. 